\title{
Controlled Release Capsule Dosage Form
}

National Cancer Institute

\section{Source}

National Cancer Institute. Controlled Release Capsule Dosage Form. NCI Thesaurus. Code C69024.

A capsule designed to release active and/or inert ing redient(s) at a controlled rate. 